\title{
ANALISIS ISOPHLET KONSENTRASI DAN ESTIMASI POTENSI PENURUNAN KARBON MONOKSIDA DI KOTA MEDAN
}

\section{ANALYSIS OF ISOPHLET CONCENTRATION AND ESTIMATION THE POTENTIAL FOR REDUCTION OF CARBON MONOXIDE IN MEDAN}

\author{
Isra' Suryati* dan Hafizhul Khair, AM \\ Program Studi Teknik Lingkungan, Universitas Sumatera Utara \\ *Email: isra.suryati@gmail.com
}

\begin{abstract}
ABSTRAK
Penelitian ini bertujuan untuk memetakan konsentrasi gas karbon monoksida (CO) di Kota Medan dan melakukan estimasi potensi penurunan karbon monoksida di beberapa ruas jalan Kota Medan dengan menerapkan transportasi massal berbasis simulasi. Penelitian ini dilakukan dengan pengambilan sampel CO di 12 (dua belas) titik di Kota Medan secara grab sampling. Konsentrasi CO dianalisis menggunakan metode NDIR dengan alat sampling yaitu CO Monitor. Hasil penelitian menunjukkan konsentrasi CO di Kota Medan antara 1145,2 $\mu \mathrm{g} / \mathrm{m}^{3}-27484,7 \mu \mathrm{g} / \mathrm{m}^{3}$. Kondisi ini masih dibawah baku mutu udara ambien nasional Peraturan Pemerintah No. 41 tahun $1999\left(30.000 \mu \mathrm{g} / \mathrm{m}^{3}\right)$. Berdasarkan peta isophlet konsentrasi tersebut bahwa titik-titik yang mempunyai konsentrasi tertinggi berlokasi di sekitar jalan salah satunya seperti di Jl. SM Raja. Untuk menurunkan konsentrasi CO di udara ambien di sekitar jalan perlu dilakukan perencanaan program dan kebijakan terkait transportasi. Apabila dilakukan skenario atau simulasi penerapan konsep transportasi massal berupa BRT CNG dan BRT Diesel di beberapa ruas jalan Kota Medan akan mampu mengurangi beban emisi CO sekitar 25,02\% sampai dengan 29,44\%.
\end{abstract}

Kata kunci : emisi kendaraan, karbon monoksida, peta isophlet, transportasi massal
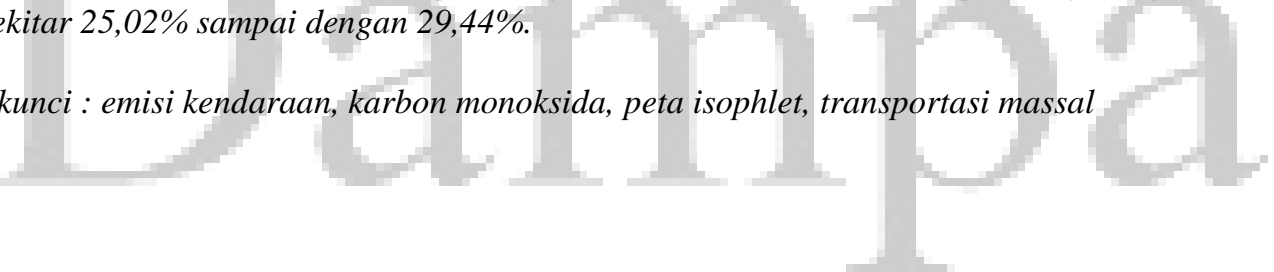

\begin{abstract}
This study aims to map the concentration of carbon monoxide $(\mathrm{CO})$ in Medan city and to estimate the potential reduction in carbon monoxide in some streets of Medan by applying mass transit based on simulation. This research was conducted by sampling $C O$ in the 12 (twelve) points in Medan by grab sampling. CO concentration was analyzed using NDIR methods by CO Monitor tools. The results showed the concentration of CO in Medan between $1145.2 \mu \mathrm{g} / \mathrm{m}^{3}-27484,7 \mu \mathrm{g} / \mathrm{m}^{3}$. This condition is still below the national ambient air quality standard of Government Regulation No. 41, 1999 (30,000 $\left.\mu \mathrm{g} / \mathrm{m}^{3}\right)$. Based on the concentration isophlet map that points that have the highest concentration located in the surrounding roadside such as at Jl. SM Raja. To reduction the CO concentration in the ambient air around the roadside is necessary to plan programs and policies related to transportation. If the scenarios or simulation with application of the concept of mass transportation such as BRT CNG and BRT Diesel in some streets of Medan then will be able to reduce CO emissions of about $25.02 \%$ to $29.44 \%$
\end{abstract}

Keywords: vehicle emissions, carbon monoxide, map isophlet, mass transit 


\section{PENDAHULUAN}

Kota Medan merupakan salah satu kota metropolitan di Indonesia. Salah satu ciri dari kota metropolitan adalah besarnya kegiatan ekonomi dan sosial sebanding dengan banyaknya jumlah penduduk. Peningkatan aktivitas ekonomi dan sosial tentunya menimbulkan permasalahan di bidang transportasi. Berdasarkan data dari Dirlantas Poldasu tahun 2014 jumlah kendaraan di Kota Medan sebanyak 5.531 .77 unit $(86,29 \%$ sepeda motor; $7,91 \%$ mobil penumpang; 4,50\% mobil barang dan 1,3\% bus) (S.Elisnawati , 2015).

Kota Medan mempunyai 4 (empat) stasiun pemantauan pencemaran udara dengan status sudah tidak aktif sejak tahun 2012. Penelitian terdahulu (Jerret et al,2005; Hoek et al, 2008 dan Hamid et al, 2015) menjelaskan bahwa pemodelan distribusi spasial dari polutan dapat membantu untuk memperkirakan konsentrasi polutan di daerah yang tidak mempunyai stasiun pemantauan pencemaran udara. Selain itu, dapat menentukan daerah yang melebihi standar polusi udara. Selanjutnya, pemodelan spasial distribusi polutan dapat dimanfaatkan untuk penilaian daerah terpapar dan studi epidemiologi.

BLH Kota Medan (2015) melakukan pemantauan kualitas udara roadside di ruas jalan Kota Medan (Jl. Gatot Subroto, Pintu masuk KIM I Mabar dan Taman Makan Pahlawan Medan) diperoleh hasil konsentrasi CO berkisar 3-20 ppm.

Penelitian terdahulu dari Yanti (2014) di daerah Kampung Lalang (Medan) diperoleh nilai $F(>1,0)$ yang berarti keadaan ruas jalan yang macet,kecepatan rendah, volume kendaraan lebih besar dari kapasitas jalan yang ada, kendaraan banyak yang mengambil bahu jalan, antrian panjang dan terjadi hambatan yang besar karena volume per kapasitas atau V/C ratio sebesar 1,08 sehingga arus lalu lintas menjadi terhambat.

Berdasarkan penelitian Tarigan (2009) tentang estimasi beban emisi kendaraan bermotor di Kota Medan untuk karbon monoksida (CO) terbesar berasal dari sepeda motor mencapai 40 ton/tahun.

Peningkatan jumlah kendaraan dan kemacetan berpengaruh terhadap emisi polutan salah satunya karbon monoksida (CO), berdasarkan data-data di atas perlu dilakukan pemetaan konsentrasi $\mathrm{CO}$ udara ambien di Kota Medan serta estimasi penurunan emisi $\mathrm{CO}$ dengan melakukan skenario pemindahan transportasi pribadi ke moda transportasi massal.

Tujuan dari penelitian ini adalah untuk mengetahui kualitas udara ambien Kota Medan dengan melakukan pemetaan konsentrasi. Peta isophlet konsentrasi ini bisa dijadikan dasar pertimbangan bagi pemerintah dalam merencanakan pengendalian dan pengelolaan udara perkotaan. Selain itu juga bertujuan untuk menghitung beban emisi karbon monoksida (CO) dari kendaran bermotor di beberapa ruas jalan Kota Medan.

Ruang lingkup penelitian ini adalah 12 (dua) belas titik sampling yang mewakili sumber transportasi, industri, perdagangan, pusat kota dan pemukiman untuk memperoleh gambaran kualitas udara ambien Kota Medan. Sementara untuk perhitungan beban emisi difokuskan pada beberapa ruas jalan di Kota Medan yaitu Jl. SM Raja, Jl. Gatot Subroto, Jl. MT Haryono dan Jl. Balai Kota. Pemilihan ruas jalan ini karena tingginya konsentrasi CO udara ambien saat sampling serta tingkat $\mathrm{V} / \mathrm{C}$ ratio yang mendekati 1 (sibuk atau padat).

Parameter yang diteliti dalam penelitian ini adalah karbon monoksida (CO). Estimasi potensi penurunan emisi dilakukan dengan skenario pemindahan tranportasi pribadi ke tranportasi massal (BRT bahan bakar CNG dan Diesel). Skenario pemindahan transportasi ini dilakukan dengan simulasi perhitungan dengan asumsi 30\% dari kendaraan pribadi beralih ke moda transportasi massal.

Pemilihan parameter ini karena parameter $\mathrm{CO}$ termasuk "silent killer" dan sumber terbanyak berasal dari aktivitas manusia seperti transportasi dan industri. Karbon monoksida (CO) merupakan suatu gas yang tidak berwarna, tidak berbau, dan tidak berasa (Langston, 2010). Gas CO dapat berbentuk cairan pada suhu $192 \square$ C.Keberadaan gas ini sebagian besar merupakan hasil pembakaran bahan bakar fosil dengan udara, berupa gas buangan. Buangan asap kendaraan bermotor juga 
merupakan salah satu penghasil gas $\mathrm{CO}$ terbesar di samping aktivitas industri (Wardhana, 2004).

Karbon monoksida memasuki aliran darah melalui paru-paru dan menempel ke hemoglobin $(\mathrm{Hb})$ yang berfungsi pembawa oksigen tubuh. Reaksi karbon monoksida dan $\mathrm{Hb}$ akan membentuk karboksihemoglobin (COHb) sehingga mengurangi pengiriman Oksigen $(\mathrm{O} 2)$ ke organ-organ tubuh dan jaringan. Pada konsentrasi yang tinggi, $\mathrm{CO}$ bersifat racun. Gejala pada individu menderita keracunan $\mathrm{CO}$ akut tergantung pada beratnya paparan seperti sakit kepala, pusing, kelemahan, mual, muntah, disorientasi, kebingungan, dan koma serta $70 \%$ atau lebih $\mathrm{COHb}$ dalam darah akan menyebabkan kematian (Nevers, 2000; J.A. Raub et al, 2002 dan Medhi, 2014).

Emisi CO yang berasal dari kegiatan transportasi dapat dihitung dengan menggunakan pendekatan jarak tempuh kendaraan yang dilewati dan volume kendaraan berdasarkan jenis kendaraan dikalikan dnegan faktor emisi (KLH, 2010). Faktor emisi (emission factor) menunjukkan perkiraan jumlah polutan yang akan diemisikan oleh tiap unit komponen kegiatan dari suatu sumber emisi (KLH, 2007).

Amini (2014) menyatakan bahwa ada 3 (tiga) cara dalam pengurangan emisi di sektor transportasi, yaitu; (a) mengurangi emisi per kilometer, (b) menerapkan transportasi massal dan (c) mengurangi jarak atau jumlah perjalanan.

Salah satu cara mengurangi emisi CO adalah dengan menerapkan transportasi massal. BRT termasuk salah satu transportasi massal yang banyak diterapkan di beberapa daerah di Indonesia. BRT merupakan bus dengan kualitas tinggi yang berbasis sistem transit yang cepat, nyaman dan biaya murah. Satu sistem BRT biasanya akan dikenakan 4-20 kali lebih kecil dari LRT dan 10 - 100 kali lebih kecil dari sistem kereta api bawah tanah (Nasrulloh, 2010).

Setiap moda transportasi akan menghasilkan emisi yang berbeda. Penelitian yang dilakukan oleh Liu, et al (2007), telah berhasil membandingkan emisi kendaraan bermotor di Beijing dan Shanghai yang hasilnya menunjukkan bahwa perbedaan emisi yang dihasilkan oleh kendaraan bermotor di kedua kota besar di China tersebut terjadi karena perbedaan kebijakan dalam bidang manajemen transportasi antar kedua kota tersebut.

Dalam penelitian Imam dan Jamrah (2012), menyebutkan bahwa secara keseluruhan emisi BRT hanya $11 \%$ - $85 \%$ dari emisi mobil penumpang.

Kota Medan sendiri sudah memiliki transportasi massal berbasis jalan yaitu Bus Trans MEBIDANG, yang beroperasi sejak November 2015 dengan jumlah armada sebanyak 30 unit (kapasitas penumpang 1 unit $=50$ orang) dengan bahan bakar solar. Daerah pelayanan Bus Trans MEBIDANG diutamakan untuk jalur antar kota dan kabupaten, bukan untuk jalur dalam kota.

Trans MEBIDANG saat ini melayani 2 (dua) koridor yaitu rute Medan - Binjai sepanjang $23 \mathrm{Km}$ dengan lintasan dari Terminal Binjai menuju Pusat Pasar dan sebaliknya. Rute jalan yang dilalui yakni Terminal BinjaiJalan Soekarno Hatta-Jalan Gatot SubrotoJalan Iskandar Muda-Jalan Gajah MadaJalan S Parman-Jalan Raden Saleh-Jalan Balai Kota-Jalan Stasiun-Jalan MT HaryoniJalan Sutomo-Jalan Pusat Pasar.

Sementara itu koridor II melayani rute Medan - Deli Serdang sepanjang $32 \mathrm{Km}$. Rute lintasan dari Pusat Pasar Medan hingga Terminal Lubuk Pakam. Rute yang dilewati yakni Pusat Pasar-Jalan Sutomo-Jalan Perintis Kemerdekaan-Jalan M Yamin-Jalan Stasiun-Jalan MT Haryono-Jalan CirebonJalan Sisingamangaraja-Jalan MedanTerminal Lubuk Pakam.

Keberadaan Trans MEBIDANG masih belum terlaksana dengan baik, hal ini dibuktikan masih sepinya penumpang di moda transportasi tersebut. Kondisi ini terjadi karena jumlah armada yang masih sedikit, jumlah halte yang kurang memadai dan kurangnya sosialisasi kepada masyarakat tentang penggunaan bus tersebut. 


\section{METODOLOGI}

\section{Lokasi dan waktu penelitian}

Penentuan jumlah titik sampling menggunakan kurva aproksimasi (KLH, 2012). Jumlah penduduk Kota Medan adalah 2. 210. 624 jiwa (BPS, 2015) dengan tingkat pencemaran rendah (BLH Kota Medan, 2015). Berdasarkan hubungan antara jumlah penduduk dan level pencemaran yang dilihat pada kurva aproksimasi diperoleh jumlah titik pemantauan kualitas udara ambien yang representatif adalah 12 (dua belas) titik sampling. Koordinat lokasi sampling dapat dilihat pada Tabel 1 berikut.

\begin{tabular}{|c|c|c|c|}
\hline \multirow{3}{*}{ No } & \multicolumn{3}{|c|}{$\begin{array}{l}\text { Tabel 1. Koordinat Titik Sampling } \\
\text { Konsentrasi CO di Kota Medan }\end{array}$} \\
\hline & \multirow[t]{2}{*}{ Nama Lokasi } & \multicolumn{2}{|c|}{ Koordinat } \\
\hline & & $\mathbf{X}(\mathbf{N})$ & $\mathbf{Y}(\mathbf{E})$ \\
\hline 1 & $\begin{array}{l}\text { Jalan Balmera } \\
\text { Belawan }\end{array}$ & $03^{\circ} 46^{\prime} 41,8^{\prime \prime}$ & $98^{\circ} 4^{\prime} 56,5^{\prime \prime}$ \\
\hline 2 & $\begin{array}{l}\text { Desa } \\
\text { Sicanang, } \\
\text { Belawan }\end{array}$ & $03^{\circ} 45^{\prime} 37,9^{\prime \prime}$ & $98^{\circ} 39^{\prime} 45,5^{\prime \prime}$ \\
\hline 3 & $\begin{array}{l}\text { Jalan SM } \\
\text { Raja }\end{array}$ & $03^{\circ} 32^{\prime} 21,0^{\prime \prime}$ & $98^{\circ} 42^{\prime} 05,0^{\prime \prime}$ \\
\hline 4 & $\begin{array}{l}\text { Jalan } \\
\text { Mangaan VIII } \\
\text { (KIM) }\end{array}$ & $03^{\circ} 39^{\prime} 59,3^{\prime \prime}$ & $98^{\circ} 40^{\prime} 56,9^{\prime \prime}$ \\
\hline 5 & $\begin{array}{l}\text { Simpang } \\
\text { Empat } \\
\text { Kampung } \\
\text { Lalang }\end{array}$ & $03^{\circ} 35^{\prime} 52,1^{\prime \prime}$ & $98^{\circ} 36^{\prime} 32,1^{\prime \prime}$ \\
\hline 6 & $\begin{array}{l}\text { Perumahan di } \\
\text { Jalan Bromo }\end{array}$ & $03^{\circ} 34^{\prime} 34,2^{\prime \prime}$ & $98^{\circ} 42^{\prime} 32,0^{\prime \prime}$ \\
\hline 7 & $\begin{array}{l}\text { Perumahan di } \\
\text { Simalingkar }\end{array}$ & $03^{\circ} 30^{\prime} 48,8^{\prime \prime}$ & $98^{\circ} 37^{\prime} 49,7^{\prime \prime}$ \\
\hline 8 & Kampus USU & $03^{\circ} 33^{\prime} 57,1^{\prime \prime}$ & $98^{\circ} 39^{\prime} 24,5^{\prime \prime}$ \\
\hline 9 & $\begin{array}{l}\text { Perumahan di } \\
\text { TASBIH }\end{array}$ & $03^{\circ} 34^{\prime} 05,8^{\prime \prime}$ & $98^{\circ} 38^{\prime} 19,6^{\prime \prime}$ \\
\hline 10 & $\begin{array}{l}\text { Jalan MT } \\
\text { Haryono } \\
\text { (Medan Mall) }\end{array}$ & $03^{\circ} 35^{\prime} 15,4^{\prime \prime}$ & $98^{\circ} 41^{\prime} 11,5^{\prime \prime}$ \\
\hline 11 & $\begin{array}{l}\text { Jalan Balai } \\
\text { Kota } \\
\text { (Merdeka } \\
\text { Walk) }\end{array}$ & $03^{\circ} 35^{\prime} 28,8^{\prime \prime}$ & $98^{\circ} 40^{\prime} 38,6^{\prime \prime}$ \\
\hline 12 & $\begin{array}{l}\text { Komplek JIP, } \\
\text { Medan Johor }\end{array}$ & $03^{\circ} 31^{\prime} 34,3^{\prime \prime}$ & $98^{\circ} 39^{\prime} 31,3^{\prime \prime}$ \\
\hline$S$ & er: Data Sc & 201 & \\
\hline
\end{tabular}

Sampling konsentrasi karbon monoksida (CO) dilakukan di ke-12 (kedua belas) titik dengan lama pengukuran untuk masingmasing sampling adalah 1 (satu) jam dengan waktu pengukuran pagi hari dan siang hari.

\section{Pengumpulan data}

Data yang dikumpulkan dalam penelitian ini terdiri data primer dan sekunder. Data primer berupa koordinat titik sampling, volume kendaraan (jenis dan jumlah kendaraan) melalui traffic counting menggunakan counter dan data konsentrasi $\mathrm{CO}$ menggunakan $\mathrm{CO}$ Monitor dengan metode analisa yaitu NDIR Analayzer.

Sampling dilakukan dengan menggunakan jasa pihak ketiga yaitu Balai Teknik Kesehatan Lingkungan Pengendalian Penyakit (BTKL-PP) Sumatera Utara.

Sementara itu untuk data sekunder yang dikumpulkan adalah data arah dan kecepatan angin untuk memperoleh windrose, data jumlah penduduk Kota Medan, data konsentrasi polutan terdahulu, data V/C ratio ruas jalan di Kota Medan, peta tata guna lahan atau peta administrasi Kota Medan untuk di-overlay dengan peta isophlet konsentrasi.

\section{Analisis Data}

Langkah pertama adalah melakukan input data koordinat sampling dan data konsentrasi CO ke dalam program Surfer 10 sehingga diperoleh peta isophlet konsentrasi. Hasil peta isophlet konsentrasi akan menunjukkan daerah/wilayah yang memiliki konsentrasi tinggi maupun rendah. Berdasarkan peta isophlet konsentrasi maka dilanjutkan penelitian untuk memecahkan permasalahan tingginya konsentrasi CO di beberapa titik di Kota Medan. Salah satu skenario yang diuji dalam penelitian ini yaitu dengan penerapan transportasi masssal di beberapa ruas jalan di Kota Medan.

Langkah kedua yaitu melakukan perhitungan emisi CO yang dihasilkan oleh kendaraan hasil traffic counting selama sampling dilakukan dengan rumus sebagai berikut:

$E_{j}=\sum_{i=1}^{n} E_{j}=\sum_{i=1}^{n} l \times P_{i} \times V \times C_{i j}$

(persamaan 1)

Keterangan :

$\mathrm{E}=$ beban emisi (g/jam)

$\mathrm{L}=$ panjang dari ruas jalan yang diamati

$(\mathrm{km})$

$\mathrm{V}=$ volume total kendaraan yang melewati ruas jalan (kendaraan/jam)

$\mathrm{Pi}=$ faktor probabilitas distribusi dari kendaraan tipe $\mathrm{i}$

$\mathrm{Cij}=$ faktor emisi kendaraan $(\mathrm{g} / \mathrm{Km})$ 
Nilai faktor emisi kendaraan bermotor seperti terlihat pada Tabel 2.

Tabel 2. Faktor emisi kendaraan bermotor

\begin{tabular}{clc}
\hline No & $\begin{array}{l}\text { Jenis } \\
\text { kendaraan }\end{array}$ & $\begin{array}{l}\text { Faktor } \\
\text { CO }(\mathbf{g} / \mathbf{k m})\end{array}$ \\
\hline $\mathbf{1}$ & Sepeda motor & 14 \\
\hline $\mathbf{2}$ & $\begin{array}{l}\text { Mobil } \\
\text { penumpang } \\
\text { (bensin) }\end{array}$ & 40 \\
\hline $\mathbf{3}$ & Bus & 11 \\
\hline $\mathbf{4}$ & Truk & 8,4 \\
\hline
\end{tabular}

Sumber: KLH, 2010

Langkah ketiga adalah melakukan estimasi penurunan emisi kendaraan menggunakan perhitungan dengan skenario pemindahan moda transportasi pribadi ke transportasi massal. Penetapan persentase pemindahan moda transportasi berdasarkan penelitian sebelumnya yaitu pemindahan moda transJakarta $\pm 20 \%$ (DNPI, 2010) dan target untuk bus Mebidang di Kota Medan adalah $\pm 32 \%$ (Dishub Kota Medan,2015) sehingga ditetapkan pada penelitian ini akan dilakukan pemindahan moda transportasi pribadi ke transportasi massal sebanyak \pm $30 \%$ dengan jenis bahan bakar yang digunakan yaitu CNG (Compresed Natural Gas) dan Diesel.

Nilai faktor emisi bus untuk CO berdasarkan jenis bahan bakar CNG adalah 8,40 dan diesel adalah 5,71 (EEA,2014). Berdasarkan perhitungan ini akan diperoleh emisi yang dihasilkan di masing-masing titik sampling sesuai dengan jenis bahan bakar dan jumlah armada bus BRT yang dibutuhkan untuk mengurangi emisi CO di udara ambien.

\section{HASIL DAN PEMBAHASAN}

\section{Peta Isophlet Konsentrasi Karbon Monoksida Kota Medan}

Pengambilan konsentrasi $\mathrm{CO}$ udara ambien dilakukan pada 12 (dua belas) titik sampling dengan waktu pengambilan pagi dan siang.

Karbon monoksida termasuk salah satu polutan yang berbahaya bagi lingkungan karena kemampuannya untuk mengikat $\mathrm{O}_{2}$ lebih kuat dibanding hemoglobin dalam darah. Peta isophlet konsentrasi CO di udara ambien Kota Medan seperti terlihat pada Gambar 1 berikut.

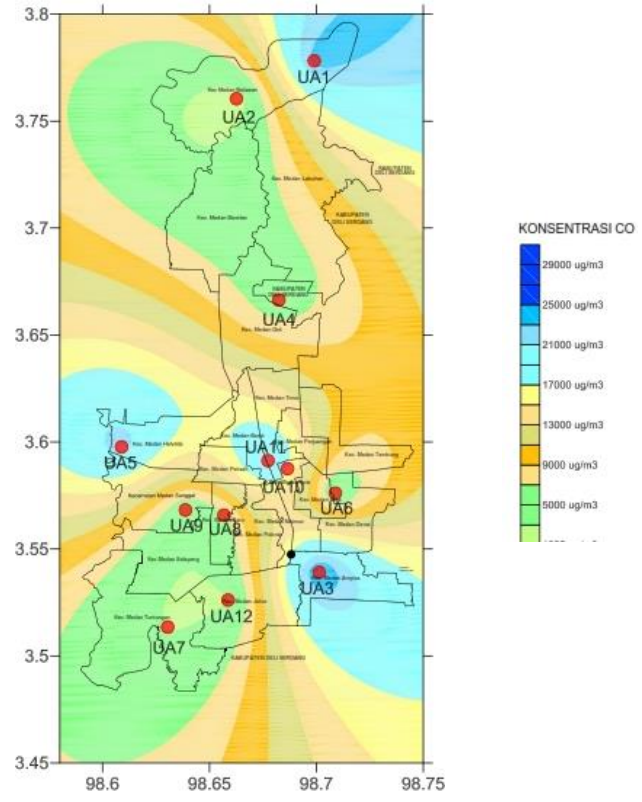

Gambar 1. Peta Isophlet Konsentrasi Karbon Monoksida di Kota Medan

Konsentrasi tertinggi $\mathrm{CO}$ dari gambar isophlet konsentrasi berada di sebagian Kecamatan Medan Belawan, Kecamatan Medan Helvetia, Kecamatan Medan Amplas dan Kecamatan Medan Barat. Tingginya konsentrasi pada lokasi ini dikarenakan jumlah emisi yang berkontribusi menurunkan kualitas udara ambien yang berasal dari kegiatan industri, lalu lintas kendaraan, perdagangan dan pusat kota.

Berdasarkan peta isophlet konsentrasi CO terlihat bahwa nilai konsentrasi tertinggi yang bersumber dari kegiatan transportasi adalah di beberapa ruas jalan yang dikategorikan sibuk. Ruas jalan tersebut adalah Jl. SM Raja, Jl. Gatot Subroto, Jl. MT Haryono dan Jl. Balai Kota.

Tingginya konsentrasi CO pada ruas jalan tersebut akan menimbulkan dampak negatif terhadap pengguna jalan baik itu pengendara motor, pejalan kaki, penjual di sekitar jalan, polisi lalu lintas dan reseptor laiinya. Salah satu cara yang dapat dilakukan adalah penerapan transportasi massal.

\section{Jenis dan Jumlah Kendaraan}

Jenis dan jumlah kendaraan pada saat pengambilan kosentrasi $\mathrm{CO}$ udara ambien dapat dilihat pada Gambar 2. 


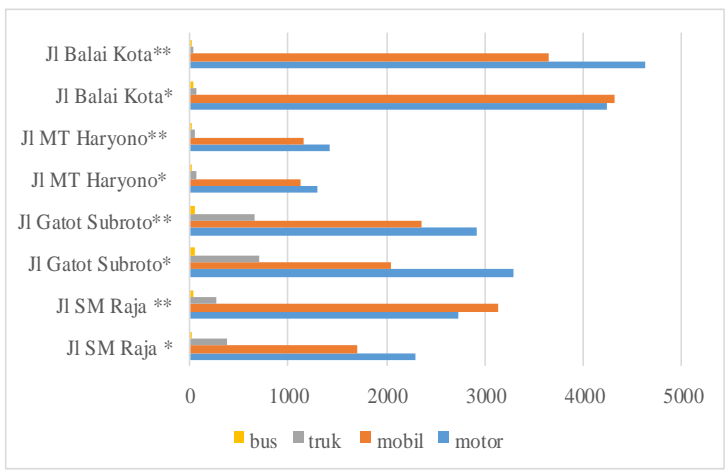

Gambar 2. Grafik Jenis dan Jumlah Kendaraan di Beberapa Ruas Jalan Kota Medan

Berdasarkan data pada Gambar 2 diatas, terlihat bahwa jenis kendaraan yang dominan untuk setiap titik adalah sepeda motor. Jumlah kendaraan terbanyak di di Jalan Balai Kota. Jalan ini dikategorikan sebagai jalan kota sehingga intensitas kendaraan pada jam sibuk meningkat. Selain itu, jalan ini berada di pusat kota yang meliputi kegiatan perkantoran, hotel dan perdagangan.

\section{Beban Emisi CO Sampling}

Berdasarkan data jenis dan jumlah kendaraan dikalikan dengan faktor emisi seperti pada persamaan (1) maka diperoleh emisi karbon monoksida di setiap titik seperti terlihat pada Tabel 4 berikut.

Tabel 4. Beban Emisi CO Total di Beberapa Ruas Jalan Kota Medan

\begin{tabular}{|c|c|c|}
\hline No & Nama Jalan & $\begin{array}{c}\text { Beban Emisi CO } \\
\text { Total (g/jam) }\end{array}$ \\
\hline 1 & J1 SM Raja* & $19.466,96$ \\
\hline 2 & Jl SM Raja ** & $31.269,36$ \\
\hline 3 & $\begin{array}{l}\text { J1 Gatot } \\
\text { Subroto* }\end{array}$ & $25.803,56$ \\
\hline 4 & $\begin{array}{l}\text { Jl Gatot } \\
\text { Subroto** }\end{array}$ & $27.479,76$ \\
\hline 5 & $\begin{array}{l}\text { J1 MT } \\
\text { Haryono* }\end{array}$ & $11.581,28$ \\
\hline 6 & $\begin{array}{l}\text { J1 MT } \\
\text { Haryono** }\end{array}$ & $11.894,04$ \\
\hline 7 & J1 Balai Kota* & $42.248,60$ \\
\hline 8 & J1 Balai Kota** & $36.745,80$ \\
\hline
\end{tabular}

Beban emisi tertinggi yaitu di Jl Balai Kota untuk pengukuran pagi hari. Hal ini terjadi karena Jl. Balai Kota sebagai pusat kota maka intensitas lalu lintas kendaraan tinggi sehingga beban emisi yang dihasilkan kendaraan juga tinggi. Kondisi ini juga membuktikan bahwa peningkatan jumlah kendaraan akan meningkatkan beban emisi di udara ambien.

\section{Estimasi Potensi Penurunan Beban Emisi dengan BRT CNG dan BRT Diesel}

Salah satu cara untuk menurunkan beban emisi CO di udara ambien yang berasal dari sektor transportasi maka dapat dilakukan dengan skenario pemindahan transportasi pribadi (sepeda motor dan mobil) ke transportasi massal berupa BRT dengan bahan bakar CNG dan bahan bakar diesel.

Bahan bakar CNG dan diesel dipilih karena bahan bakar ini mengemisikan $\mathrm{CO}$ lebih rendah dibanding bahan bakar solar dan bensin. Hal ini bisa dilihat dari faktor emisi BRT CNG untuk parameter CO adalah 8,4 $\mathrm{g} / \mathrm{km}$ dan BRT Diesel adalah 5,71 g/km.

Dalam penelitian ini dilakukan skenario atau simulasi pemindahan moda transportasi sebesar 30\% sehingga diperoleh beban emisi CO seperti pada Gambar 3 berikut.

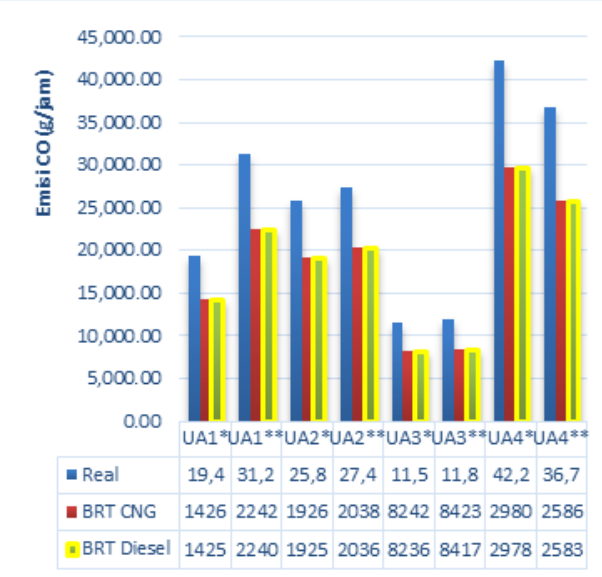

\section{Gambar 3. Perbadingan Emisi CO dengan Penggunaan BRT CNG dan BRT Diesel}

Pada gambar 3, terlihat apabila terjadi perpindahan moda transportasi sebesar 30\% maka diperoleh penurunan emisi $\mathrm{CO}$ dengan menggunakan BRT CNG berkisar 25,02\% $29,28 \%$ dan untuk BRT Diesel berkisar $25,17 \%$ - 29,44\%. Rentang penurunan emisi CO antara BRT CNG dengan BRT Diesel tidak terlalu berbeda jauh. Hal ini terjadi 
karena nilai faktor emisi antara BRT CNG dengan BRT Diesel yang juga tidak berbeda jauh. Energi yang dihasilkan oleh kendaraan berbahan bakar CNG lebih rendah dibanding diesel sehingga dibutuhkan konsumsi CNG yang lebih banyak (Yustinus, 2013). Kondisi ini mempengaruhi kemampuan untuk menurunkan emisi CO.

Perhitungan estimasi penurunan beban emisi ini juga memprakirakan kebutuhan armada BRT baik berbahan bakar Diesel maupun CNG di Kota Medan rata-rata per segmen jalan berkisar \pm 75 unit.

Penambahan armada BRT CNG dan Diesel ini perlu ditindaklanjuti dengan peningkatan kualitas jalan dan ketersediaan halte bus.

\section{Hasil Sampling Konsentrasi CO Ambien}

Hasil perbandingan pengukuran konsentrasi $\mathrm{CO}$ udara ambien di beberapa ruas jalan di Kota Medan dengan baku mutu udara ambien nasional (PP No. 41 tahun 1999) dimana ambang batas untuk $\mathrm{CO}$ pengukuran 1 jam adalah $30.000 \mu \mathrm{g} / \mathrm{m}^{3}$ disajikan pada Gambar 4 berikut.

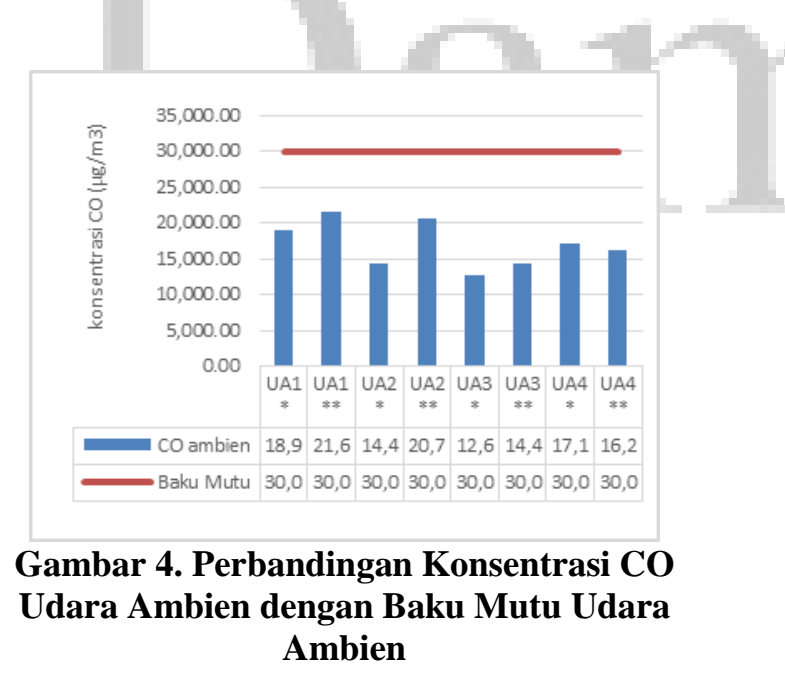

Berdasarkan Gambar 4 di atas, terlihat bahwa konsentrasi $\mathrm{CO}$ di udara ambien beberapa ruas jalan di Kota Medan masih memenuhi baku mutu udara ambien nasional. Konsentrasi CO udara ambien tertinggi terjadi pada titik UA1** (J1 SM Raja pengukuran siang hari). Tingginya konsentrasi di titik ini dikarenakan sumber emisi dari lalu lintas kendaraan. J1 SM Raja dikategorikan jalan nasional yang merupakan jalan lintas dari dan ke Kota Medan.

\section{Analisis Pengaruh Emisi CO terhadap Konsentrasi CO Ambien}

Untuk mengetahui pengaruh beban emisi CO terhadap kualitas udara ambien dilakukan uji korelasi antara emisi $\mathrm{CO}$ dengan $\mathrm{CO}$ udara ambien. Hasil uji korelasi antara beban emisi CO dengan konsentrasi $\mathrm{CO}$ udara ambien diperoleh nilai $\mathrm{R}=0,5$. Nilai $R=0,5$ menunjukkan bahwa hubungan korelasinya sedang. Hal ini terjadi karena banyak faktor yang mempengaruhi emisi $\mathrm{CO}$ di udara ambien diantaranya adalah faktor meteorologi seperti suhu, kelembaban, arah angin dan kecepatan angin.

Selain faktor meteorologi, emisi gas buang kendaraan bermotor juga dipengaruhi karakteristik mesin, umur kendaraan, jenis bahan bakar serta perawatan mesin kendaraan.

\section{SIMPULAN}

Penelitian pemetaan kualitas udara ambien di Kota Medan untuk parameter $\mathrm{CO}$ memperlihatkan konsentrasi $\mathrm{CO}$ di beberapa lokasi sampling cukup tinggi yaitu berkisar $1145,2 \mu \mathrm{g} / \mathrm{m}^{3}-27484,7 \mu \mathrm{g} / \mathrm{m}^{3}$. Angka konsentrasi CO udara ambien sampling di bulan Agustus 2016 masih berada di bawah baku mutu udara ambien. Beberapa ruas jalan di Kota Medan menunjukkan beban emisi $\mathrm{CO}$ yang dihasilkan berkisar $11.581,28 \mathrm{~g} / \mathrm{jam}-42.248,6 \mathrm{~g} / \mathrm{jam}$.

Penurunan beban emisi CO dapat dilakukan salah satunya adalah pemindahan moda transportasi pribadi (sepeda motor dan mobil $\pm 30 \%$ ke transportasi massal seperti BRT dengan bahan bakar CNG dan Diesel. Pemindahan moda transportasi ini mengurangi emisi $\mathrm{CO}$ ke udara ambien sekitar 25,02 \% - 29,44 \%. Jumlah armada BRT CNG dan Diesel yang dibutuhkan adalah \pm 75 unit per ruas jalan.

Penerapan transportasi massal dalam rangka untuk menurunkan konsentrasi $\mathrm{CO}$ di udara ambien perlu mempertimbangkan aspek penting lainnya seperti kelayakan jalan (ruas jalan dan kondisi fisik jalan), ketersediaan halte bus. Kelayakan secara teknis perlu ditunjang kelayakan secara sosial masyarakat seperti sosialisasi program, rencana dan kebijakan terkait penerapan transportasi massal. 
Hasil penelitian juga menunjukkan bahwa jenis dan jumlah kendaraan berkorelasi kuat dengan emisi CO. Sementara itu beban emisi $\mathrm{CO}$ berkorelasi sedang dengan konsentrasi udara ambien karena ada beberapa faktor yang mempengaruhi pendispersian polutan di udara ambien, salah satunya adalah faktor meteorologi. Perlu dilakukan penelitian lebih lanjut pengaruh faktor meteorologi dan kendaraan (mesin, umur, jadwal perawatan) terhadap beban emisi CO dan konsentrasi $\mathrm{CO}$ di udara ambien.

\section{UCAPAN TERIMAKASIH}

Pada kesempatan ini penulis mengucapkan terima kasih banyak kepada Lembaga Penelitian USU yang telah mendanai penelitian ini, BTKL-PP Medan dalam pengambilan sampling kualitas udara ambien, mahasiswa/i yang telah membantu dalam survey di lapangan serta semua pihak yang membantu dalam pelaksanaan penelitian ini.

\section{DAFTAR PUSTAKA}

Amini, H. A. (2014). Analisis Pengurangan Emisi Karbon Dari Penggunaan Kereta Api Prambanan Ekspres Rute Yogyakarta-Solo Tahun 2014. Sekolah Arsitektur, Perecanaan dan Pengembangan Kebijakan. ITB: Bandung.

BLH Kota Medan (2015). Laporan Pemantauan Roadside Kota Medan Tahun 2014 dan 2015. BLH Kota Medan. Medan

BPS Provinsi Sumatera Utara (2015). Kota Medan dalam Angka tahun 2015. BPS. Provinsi Sumatera Utara.

Dishub Kota Medan (2015). Studi Pengembangan Angkutan Massal Berbasis Jalan yang Ramah Lingkungan Dan Hemat Energi. Medan

DNPI. (2010). Laporan Teknis Peluang dan Kebijakan Pengurangan Emisi Sektor Transportasi

EEA. (2014). EMEP/EEA emission inventory guidebook 2013.

Publications Office of the European Union. Luxembourg.

Hamid, T S., Davood, S., Saeed,S., Majid, H., Nokhandan. (2015). Evaluation of MARS for the spatial distribution modeling of carbon monoxide in an urban area. Journal of Atmospheric Pollution Research 6, 581 - 588.

Hoek, G., Beelen, R., de Hoogh, K., Vienneau, D., Gulliver, J., Fischer, P.,Briggs, D. (2008). A review landuse regression models to assess spatial variation of outdoor air pollution. Atmospheric Environment 42, 7561-7578.

J.A.Raub and V.A. Benignus. (2002). Carbon monoxide and nervous system. Neuroscience and Biobehavioral Reviews 26, 925-940.

Jerret., M., Burnett, R.T., Ma, R.J., Pope, C.A., Krewski, D., Newbold, K.B ., Thurston, G., Shi, Y.L., Finkelstein, N., Calle, E.E., Thun, M.J. (2005). Spatial analysis of air pollution and mortality in Los Angeles. Epidemiology 16, 727-736.

KLH.(2007). Memprakirakan Dampak Lingkungan: Kualitas Udara. Deputi Bidang Tata Lingkungan Hidup KeMenLH. Jakarta

KLH. (2010). Peraturan Pemerintah No. 12 tahun 2010 tentang Pelaksanaan Pengendalian Pencemaran Udara di Daerah. . KeMenLH. Jakarta

Liu, H., He, K., Wang, G., Huo, H., Lents, J., Davis, N. Chen, Ch., Osses, M., and $\mathrm{He}$ Ch. (2007). Comparison of Veicle Activity and Emission Inventory Between Beijing and Shanghai, Journal of Air \& Waste Management Association 57.

Medhi, F., Roohollah, R., Sadegh, $\mathrm{H}$ and Ali, R. (2015). Concentration of Carbon Monoxide in indoor and outdoor air of Ghalyun cafes. Journal of Atmospheric Pollution Research 6, $550-555$.

Nasrulloh, M. (2010). Sistem Bus Rapid Transit di Jakarta: Integrasi Perkotaan dan Dampak Lingkungan. Skripsi. Teknik Sipil, Universitas Indonesia. Depok.

Nevers, N. d. (2000). Air Pollution Control Engineering. Second Edition. Mc Graw Hill Companies: Singapore

Sibarani, E. (2015). Hubungan Paparan Kebisingan dan Karakteristik Operator SPBU Terhadap Tekanan Darah Di Kecamatan Medan Sunggal Tahun 2015. Skripsi. Fakultas 
Kesehatan Masyarakat. Universitas Sumatera Utara. Medan.

Tarigan, A. (2009). Estimasi Emisi Kendaraan Bermotor Di Beberapa Ruas Jalan Kota Medan. Tesis. Universitas Sumatera Utara. Medan

Wardhana, W. A. (2004). Dampak Pencemaran Lingkungan. Cetakan keempat.Yogyakarta : Penerbit ANDI. Yanti, M. (2014). Pengaruh Aktivitas Pasar Terhadap Tingkatan Pelayanan (Studi Kasus : Pasar Kampung Lalang). Tesis. Universitas Sumatera Utara. Medan.
Yustinus, S, Semin dan Tjoek, S. (2013). Analisis Perbandingan Emisi Gas Buang Mesin Diesel Menggunakan Bahan Bakar Solar dan CNG Berbasis Simulasi. Jurnla Teknik Sistem Perkapalan Vol.1, No.1.hal 1-5. ITS. Surabaya.

Slamet, R., Yenni, R., dan Rizki, A., 2013. Studi Pemanfaatan Sampah Di Universitas Andalas. Vol.10 (1) : 77-82. SNI 19-2454-2002 tentang Tata Cara Teknik Operasional Sampah Perkotaan.

SNI 3242-2008 tentang Pengelolaan Sampah di Permukiman.

Undang-Undang Nomor 18 Tahun 2008 tentang Pengelolaan Sampah.

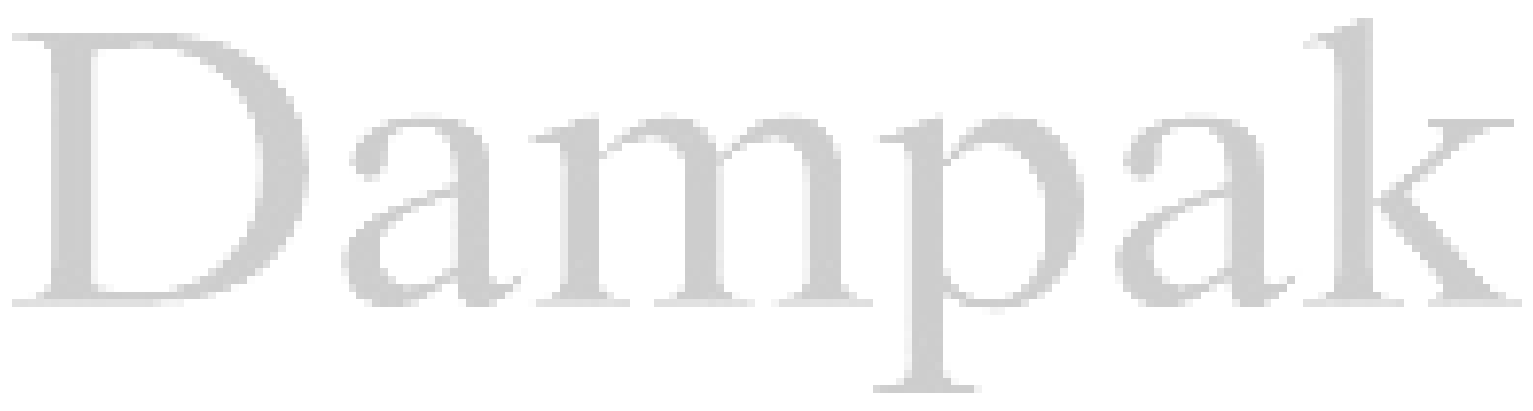

